\title{
PRODUKTIVITAS DAN BIAYA PENGELUARAN KAYU DARI HUTAN TANAMAN DENGAN SISTEM KABEL LAYANG P3HH24 DI KPH PEKALONGAN BARAT
}

\section{(Productivity and Cost of Log Extraction Using P3HH24 Skyline System in Plantation Forest of West Pekalongan Forest District)}

Oleh/By :

\author{
Dulsalam $^{1)} \&$ Djaban Tinambunan ${ }^{1)}$
}

\begin{abstract}
A study on productivity and cost of log extraction using P3HH24 skyline system was carried out in plantation forest of West Pekalongan Forest District. The objective is to find out the productivity and cost, as well as various operational aspects of log extraction using $\mathrm{P} 3 \mathrm{HH} 24$ skyline system. The study results revealed that:

1. Operating P3HH24 skyline system for log extraction in plantation forest of West Pekalongan Forst District was running well.

2. Extracted log diameter ranged from 20 to $51 \mathrm{~cm}$ with an average of $36 \mathrm{~cm}$ while the average number of logsperturn varied from 1 to 3 logs with the volume varied from 0.040 to $0.500 \mathrm{~m}^{3} /$ turn with an average of $0.163 \mathrm{~m}^{3} /$ turn.

3. The productivity of log extraction varied from 1.527 to $5.656 \mathrm{~m}^{3} /$ hour with an average of $2.519 \mathrm{~m}^{3} /$ hour while an average cost of log extraction was $\mathrm{R} p 15.713 / \mathrm{m}^{3}$.

4. Compared to local standard cost of log extraction, the cost of log extraction using P3HH24 skyline system was cheaper and, therefore, it was feasible to be applied.

5. In the forest areas having slopes of $15 \%$ and up, it is recommended to use P3HH24 skyline system for log extraction.
\end{abstract}

Keywords: Plantation forest, P3HH24 skyline system, productivity, cost

\begin{abstract}
ABSTRAK
Penelitian produktivitas dan biaya pengeluaran kayu dengan sistem kabel layang P3HH24 telah dilakukan di hutan tanaman KPH Pekalongan Barat pada tahun 2002. Tujuannya untuk mendapatkan informasi tentang produktivitas, biaya pengeluaran kayu dan berbagai aspek operasional sistem kabel layang tersebut.
\end{abstract}

\footnotetext{
${ }^{1)}$ Peneliti pada Pusat Penelitian dan PengembanganHasil Hutan, Bogor
} 
Hasil penelitian menunjukkan bahwa :

1. Pengoperasian kabel layang $\mathrm{P} 3 \mathrm{HH} 24$ untuk mengeluarkan kayu di hutan tanaman $\mathrm{KPH}$ Pekalongan Barat dapat berjalan lancar.

2. Diameter kayu yang dikeluarkan berkisar antara $20-51 \mathrm{~cm}$ dengan rata-rata $36 \mathrm{~cm}$, sedangkan jumlah batang yang disarad per satu tahap operasi (rit) berkisar antara 1 - 3 batang dengan volume berkisar antara $0,040-0,500 \mathrm{~m}^{3} /$ rit dengan rata-rata $0,163 \mathrm{~m}^{3} /$ rit.

3. Produktivitas pengeluaran kayu berkisar antara $1,527-5,656 \mathrm{~m}^{3} /$ jam dengan rata-rata 2,519 $\mathrm{m}^{3} /$ jam, sedangkan biaya rata-rata pengeluaran kayu adalah $\mathrm{Rp} 15.713 / \mathrm{m}^{3}$.

4. Dibandingkan dengan upah pengeluaran kayu setempat, pengeluaran kayu dengan sistem kabel layang P3HH24 jauh lebih murah sehingga layak diusahakan.

5. Untuk pengeluaran kayu pada areal yang mempunyai kelerengan $15 \%$ ke atas, disarankan untuk menggunakan sistem kabel layang P3HH24.

Kata kunci: Hutan tanaman, sistem kabel layang P3HH24, produktivitas, biaya

\section{PENDAHULUAN}

Luas hutan tanaman industri yang sekarang dikenal dengan hutan tanaman baru lebih dari dua juta hektar. Jumlah Hak Pengusahaan Hutan Tanaman (HPHT) sampai akhir 2002 berjumlah 230 unit dengan pencadangan areal seluas 6,9 juta ha. Realisasi pembangunan hutan tanaman sampai akhir 2003 seluas sekitar 2,5 juta ha. Produksi kayu rata-rata pada tahun 1998 - 2002 adalah sekitar 14 juta $\mathrm{m}^{3}$ / tahun dan cenderung menurun pada dua tahun terakhir kecuali produksi kayu dari hutan tanaman. Produksi kayu dari hutan tanaman cenderung meningkat dengan produksi kayu rata-rata sekitar 3,8 juta $\mathrm{m}^{3} /$ tahun (Laban, 2004).

Sebagian dari luas hutan tanaman tersebut ada yang sudah dapat dimanfaatkan terutama untuk bahan baku industri pulp (untuk hutan tanaman di luar Jawa) dan bahan bangunan (untuk hutan tanaman di Jawa). Dalam usaha pemanfaatan hutan tersebut, kegiatan pertama yang dilakukan adalah pemungutan kayu. Pemungutan kayu dibagi lagi ke dalam beberapa sub kegiatan, yaitu penebangan, pengeluaran kayu, muat bongkar dan pengangkutan kayu.

Sampai saat ini alat pengeluaran kayu yang digunakan di hutan tanaman biasanya adalah traktor. Untuk mengeluarkan kayu di areal hutan tanaman yang mempunyai kelerengan tinggi, alat tersebut kurang ekonomis. Sebagai contoh hutan tanaman tusam di Jawa Barat biasanya terletak di daerah perbukitan. Hutan tanaman di Pulau Jawa kurang lebih 30\% berada pada topografi yang bergelombang. Sistem kabel layang merupakan salah satu alternatif pengeluaran kayu di areal yang mempunyai kelerengan cukup tinggi tersebut. Keuntungan penggunaan sistem kabel layang adalah tidak merusak permukaan tanah, kayu tetap bersih dan segar sehingga mudah untuk diproses dan pengeluaran kayu relatif cepat. Sistem pengeluaran kayu yang mungkin cocok dioperasikan di areal hutan dengan kelerengan cukup tinggi adalah sistem kabel layang yang menggunakan tenaga mesin. Sistem kabel layang ini dicirikan dengan adanya mesin penggerak (yarder) yang bekerja pada posisi diam (stasioner) dan sanggup menarik kayu pada jarak tertentu dengan kabel yang digulung pada sebuah drum sambil membawa kayu dengan kereta (carriage) yang meluncur di atas kabel layang yang ditopang oleh beberapa tiang utama dan tiang pembantu.

Sistem kabel layang memerlukan beberapa peralatan utama. Brown (1949) menyatakan bahwa peralatan utama yang diperlukan dalam sistem kabel adalah: (1) Unit mesin penggerak di mana unit ini berfungsi sebagai sumber tenaga seluruh sistem kabel; (2) Kabel baja dan 
pengikatnya termasuk penjepit dan macam-macam perlengkapan yang dapat saling dihubungkan; (3) Kabel dan kereta yang berfungsi untuk mengarahkan perpindahan kayu dan diletakkan berhubungan dengan kabel-kabel.

Wackerman (1949) menyatakan bahwa metode kabel layang (skyline) merupakan metode mekanis yang makin berkembang dan menjadi paling lengkap dari pengeluaran kayu sistem kabel. Pada metode ini terdapat modifikasi berdasarkan cara pemasangan kabel layang, kereta dan penggunaan kabel pelengkapnya. Penggunaan metode kabel layang berubah berdasarkan kebutuhan medan yang dihadapi dan perubahan modifikasinya tergantung pada cara pemakaiannya bukan pada peralatan yang dipergunakannya.

Penggunaan sistem kabel layang dipengaruhi oleh beberapa faktor. Binkley dan Lysons (1968) menjelaskan bahwa secara ekonomis pengoperasian sistem kabel layang harus mempertimbangkan faktor-faktor sebagai berikut : (1) Konversi dari nilai kayu yang dikeluarkan; (2) Total volume kayu setiap hektar yang akan dikeluarkan pada sebuah lokasi penebangan; (3) Areal unit penebangan yang belum dikeluarkan hasilnya. (4) Jumlah hari kerja efektif dalam satu tahun; (5) Ukuran dari kayu yang akan dikeluarkan; dan (6) Jarak pengeluaran kayu.

Sortimen kayu yang dikeluarkan di areal hutan tanaman yang mempunyai kelerengan cukup tinggi umumnya mempunyai volume $0,50-1,00 \mathrm{~m}^{3} /$ batang. Padahal kemampuan alat pengeluaran kayu P3HH20 generasi kesatu hanya $0,308 \mathrm{~m}^{3} /$ rit dan $\mathrm{P} 3 \mathrm{HH} 20$ generasi kedua hanya $0,360 \mathrm{~m}^{3} /$ rit (Dulsalam et al., 1997). Pada tahun 1998 alat pengeluaran kayu tersebut telah disempurnakan. Volume kayu rata-rata yang disarad dengan sistem kabel layang P3HH20 yang telah disempurnakan per rit di bawah $0,5 \mathrm{~m}^{3} /$ rit. Dulsalam et al. (1997) menyatakan bahwa produktivitas pengeluaran kayu tanpa memperhitungkan waktu pasang dan bongkar alat dengan sistem kabel layang P3HH20 berkisar antara 0,575-5,058 $\mathrm{m}^{3} / \mathrm{jam}$ dengan rata-rata $1,856 \mathrm{~m}^{3} / \mathrm{jam}$. Pengeluaran kayu dengan sistem kabel layang P3HH20 di areal perbukitan masih mengalami beberapa hambatan, antara lain pada saat kayu ditarik untuk diangkat, kayu tersebut berputar sehingga kabel pengangkat ikut berputar yang mengakibatkan kabel pengangkat tersebut menjepit kereta. Keadaan yang demikian tidak memungkinkan untuk pengangkatan kayu karena apabila dipaksakan, selain mesin tidak kuat, kabel pengangkat dapat putus. Hal ini disebabkan karena bentuk kereta yang terlalu pendek dan kecil.

Untuk memperlancar kegiatan penarikan kayu maka kereta telah disempurnakan. Di samping masalah kereta, tenaga mesin dan sistem pengereman telah disempurnakan pula. Tenaga yarder menggunakan mesin disel lebih besar yang berkekuatan 24 tenaga kuda (HP). Sistem pengereman digunakan sistem ikat pinggang, yaitu tromol ditekan dari luar dengan pita rem yang bermata fiber glass. Alat yang telah disempurnakan ini diberi nama sistem kabel layang $\mathrm{P} 3 \mathrm{HH} 24$.

Berdasarkan latar belakang permasalahan tersebut maka telah dilakukan penelitian produktivitas dan biaya pengeluaran kayu dengan sistem kabel layang P3HH24 di KPH Pekalongan Barat pada tahun 2002. Tujuan dari penelitian ini adalah untuk membuktikan bahwa alat pengeluaran kayu dengan sistem kabel layang hasil rekayasa Pusat Litbang Hasil Hutan tersebut dapat digunakan untuk mengeluarkan kayu yang layak secara teknis dan ekonomis di areal hutan tanaman yang mempunyai kelerengan cukup tinggi. Sedangkan sasarannya adalah tersedianya sistem pengeluaran kayu di areal hutan tanaman yang mempunyai kelerengan cukup tinggi. 


\section{METODE PENELITIAN}

\section{A. Pendekatan Masalah}

Penelitian pengeluaran kayu dengan sistem kabel di hutan tanaman dilakukan dengan menguji coba alat pengeluaran kayu menggunakan sistem kabel layang hasil rekayasa Pusat Litbang Hasil Hutan (P3HH) Bogor di lapangan. Variabel atau peubah dalam uji coba ini adalah produktivitas dan biaya pengeluaran kayu. Sedangkan parameter (kriteria pengamatan) dalam penelitian ini adalah waktu kerja yang dihitung dalam satuan jam, diameter kayu yang di hitung dalam meter, panjang kayu yang dikeluarkan dan diukur dalam satuan meter, biaya penyusutan yang diukur dalam rupiah per jam, biaya bunga yang diukur dalam Rp/jam, biaya bahan bakar yang diukur dalam Rp/jam, biaya oli (minyak pelumas) yang diukur dalam $\mathrm{Rp} / \mathrm{jam}$, biaya perbaikan yang diukur dalam $\mathrm{Rp} / \mathrm{jam}$, dan biaya upah tenaga kerja yang diukur dalam Rp/jam. Pengeluaran kayu dengan alat pengeluaran kayu yang dibuat oleh $\mathrm{P} 3 \mathrm{HH}$ mempunyai produktivitas yang lebih tinggi dan memerlukan biaya yang lebih rendah sehingga alat tersebut layak secara teknis dan ekonomis.

\section{B. Lokasi dan Obyek Uji Coba}

Lokasi penelitian adalah di daerah KPH Pekalongan Barat, Perum Perhutani Unit I Jawa Tengah. Obyek penelitian adalah pengeluaran kayu yang meliputi penebangan kayu yang akan dikeluarkan, pemotongan kayu, mengait kayu, menarik kayu, bongkar muatan dan ambil muatan yang ditinjau dari aspek teknis dan ekonomi di areal hutan tanaman yang mempunyai kelerengan cukup tinggi.

\section{Bahan dan Alat Penelitian}

Bahan yang digunakan untuk penelitian ini adalah: (1) Sakel (sachle) $10 \mathrm{~cm}$; (2) Sakel (sacble) $12 \mathrm{~cm}$; (3) Penjepit kabel diameter $8 \mathrm{~mm}$; (4) Penjepit kabel diameter $12 \mathrm{~mm}$; (5) Penjepit kabel diameter 14 mm; (6) Kabel baja diameter 10 mm; (7) Kabel baja diameter 14 mm; (8) Kabel baja diameter 18 mm; (9) Katrol besar; dan (10) Katrol kecil.

Alat yang digunakan dalam penelitian ini adalah sebagai berikut: (1) Peralatan kunci; (2) Mesin las; (3) Mesin bubut; (4) Mesin bor; (5) Pahat besi; (6) Pemotong kabel; (7) Komputer; (8) Palu; (9) Tirfor 1,5 ton; (10) Tirfor 3 ton; (11) Mesin gurinda; (12) Gergaji besi; (13) Alat tulis menulis; (14) Meteran; (15) Alat pengukur waktu (stop watch); dan (16) Yarder P3HH24 (sketsanya dapat dihat pada Lampiran 1).

\section{Prosedur}

Penyempurnaan alat dilakukan di Laboratorium P3HH Bogor pada tahun 2002. Penyempurnaan alat meliputi sistem rem dan tenaga motor. Sistem pengereman menggunakan tromol yang ditekan dari luar dengan pita rem yang terbuat dari besi plat di mana pada salah satu sisi yang dekat dengan tromol dilapisi fiber glass. Fiber glass ini berfungsi sebagai kampas (bantalan) rem. Penyempurnaan tenaga motor dilakukan dengan cara mengganti mesin disel lama yang bertenaga motor $20 \mathrm{HP}$ dengan mesin disel baru yang bertenaga motor $24 \mathrm{HP}$. 
Desain (rancangan) uji coba adalah deskriptif di mana mengikuti kegiatan pengeluaran kayu yang biasa dilakukan di lapangan. Penarikan contoh dilakukan secara purposif (tidak acak) dengan pertimbangan kemudahan lokasi untuk dijangkau dan demi tercapainya tujuan penelitian, tetapi tetap dapat mewakili populasi.

Prosedur kerja penelitian pengeluaran kayu dengan sistem kabel di hutan tanaman adalah sebagai berikut: (1) Mempelajari pustaka; (2) Membuat daftar isian; (3) Mencatat data operator penebang dan operator yarder; (4) Mencatat kondisi medan penebangan dan pengeluaran kayu; (5) Membuat petak uji coba (Skema sistem kabel disajikan pada Lampiran 2.); (6) Mencatat waktu kerja (dalam detik), pemakaian bahan bakar (dalam liter per jam) dan situasi saat pengeluaran kayu; (7) Mengukur hasil kerja pada kegiatan pengeluaran kayu; (8) Mencatat upah tenaga kerja (Rp/hari); dan (9) Mencatat biaya pemilikan alat (Rp).

Prosedur pengeluaran kayu dengan sistem kabel layang P3HH24 terdiri dari persiapan pengeluaran kayu, dan pemasangan alat dan pengoperasianya. Persiapan pengeluaran kayu meliputi kegiatan orientasi lapangan dan penebangan pohon di jalur kabel. Kegiatan pemasangan alat terdiri dari penempatan yarder dan pemasangan kait, pemasangan kabel penguat (guyline) dan katrol pada tiang utama, pemasangan kabel penguat dan katrol pada tiang pembantu, dan pemasangan kabel layang dan kabel tanpa ujung.

Pengoperasian alat sistem kabel layang P3HH24 dapat dijelaskan seperti berikut ini. Setelah kabel layang dan kereta berikut kabel utama dipasang dan mesin telah dipanaskan maka pekerjaan pengeluaran kayu dapat dimulai. Pengoperasian sistem kabel layang ini dilayani oleh enam orang, yaitu satu orang operator mesin, dua orang melepas kait di tempat pengumpulan, satu orang memberi tanda di tempat kayu dikeluarkan, satu orang mengait kayu, dan dua orang menyiapkan kayu. Unsur kerja pertama pada pengoperasian alat adalah meluncurkan kereta dari panggung atas (lokasi di mana yarder berada) ke panggung bawah (lokasi di mana kayu yang akan dikeluarkan berada). Setelah kereta sampai di sekitar kayu yang akan dikeluarkan, pemasang kait memberi tanda untuk menghentikan kereta dan mengendorkan kabel utama. Selanjutnya setelah kabel utama ada di bawah maka kayu yang sudah disiapkan dikaitkan ke katrol yang ada pada kabel utama, kemudian kabel utama ditarik dan muatan akan terangkat ke atas di bawah kereta. Kereta ditarik dengan kabel utama maka muatan akan bergerak ke unit yarder. Apabila kayu telah sampai di panggung atas, kabel tanpa ujung direm dan kabel utama dikendorkan maka muatan akan turun. Setelah muatan turun di tempat pengumpulan sementara, kait pada muatan di lepas dan dengan demikian satu siklus pengeluaran kayu selesai. Selanjutnya kereta diluncurkan menuju ke lokasi kayu yang akan dikeluarkan untuk melaksanakan siklus selanjutnya sesuai dengan urutan di atas.

Setelah kegiatan pengoperasian alat selesai maka dilakukan pembongkaran alat. Pembongkaran alat dilakukan seperti uraian berikut ini. Pembongkaran alat dibedakan menjadi dua kegiatan, yaitu pembongkaran pada unit yarder dan pembongkaran pada tiang pembantu. Kegiatan pertama pada pembongkaran alat adalah mengendorkan (menurunkan tegangan dengan cara mengulur) kabel layang. Setelah itu, kereta, kabel layang dan kabel tanpa ujung dilepas. Pekerjaan selanjutnya adalah menggulung kabel pengangkat dengan mesin dan menggulung kabel tanpa ujung secara manual. Pembongkaran pada tiang utama dan tiang pembantu adalah pembongkaran katrol-katrol beserta perlengkapan pengikatnya. Perlengkapan yang telah dilepas dikumpulkan di tempat unit yarder dan selanjutnya siap untuk diangkut ke tempat lain. 


\section{E. Analisis Data}

Hasil pengamatan di lapangan telah dianalisis dan dikaji pada akhir kegiatan untuk menentukan cara pengeluaran kayu di areal hutan tanaman yang mempunyai kelerengan cukup tinggi. Analisis data dilakukan secara tabulasi. Alat analisis yang digunakan adalah ratarata (mean). Rumus-rumus yang digunakan dalam pengolahan data adalah sebagai berikut:

1) Untuk menghitung produktivitas alat dihitung dengan rumus :

$$
\mathrm{P}=\frac{\sum_{\mathrm{i}=1}^{\mathrm{n}} \mathrm{Vi}}{\mathrm{Wa}_{\mathrm{a}}+\mathrm{Wo}_{\mathrm{O}}+\mathrm{Wb}_{\mathrm{b}}}
$$

di mana : $\mathrm{P}=$ Produktivitas alat atau ekstraksi $\left(\mathrm{m}^{3} / \mathrm{jam}\right) ; \mathrm{Vi}=$ Volume kayu yang dikeluarkan pada batang kayu ke $i$, Wa $=$ Waktu rata-rata persiapan dan pemasangan alat (jam); Wo = Waktu operasi; Wb = Waktu rata-rata bongkar alat (jam); dan $\mathrm{n}=$ Jumlah batang kayu/rit.

2) Volume kayu yang dikeluarkan dihitung dengan rumus sebagai berikut :

$$
\mathrm{V}=1 / 4 \pi \mathrm{D} 2 \times \mathrm{L}
$$

di mana: $V=$ Volume kayu $\left(\mathrm{m}^{3}\right) ; \pi=22 / 7 ; \mathrm{D}=$ Diameter rata-rata (pangkal dan ujung) kayu (m); dan L= Panjang kayu (m).

Dalam menghitung biaya dibedakan biaya tetap dan biaya tidak tetap. Yang dimaksud biaya tetap adalah biaya penghapusan, biaya asuransi, bunga dan pajak. Biaya tidak tetap meliputi biaya bahan bakar, pelumas, perawatan dan perbaikan, suku cadang dan tenaga kerja. Perhitungan biaya adalah sebagai berikut:

1) Biaya penghapusan (Wackerman, 1949):

$$
\mathrm{D}=\frac{\mathrm{M}-\mathrm{R}}{\mathrm{Nt}}
$$

di mana : $\mathrm{D}=$ Penyusutan alat/biaya penghapusan $(\mathrm{Rp} / \mathrm{jam}) ; \mathrm{M}=\operatorname{Investasi}$ alat $(\mathrm{Rp}) ; \mathrm{R}=$ Nilai bekas alat (Rp); $\mathrm{N}=$ Waktu ekonomis alat (tahun); dan $\mathrm{t}=$ Waktu operasi alat (jam/tahun).

2) Biaya bunga modal dihitung dengan rumus berikut (Anonim,1992) : 
Biaya bunga modal $=\frac{\operatorname{Harga} \text { alat }(\mathrm{Rp}) \times 0,6}{\text { Umur pakai alat per tahun (jam) }} \times 0.18$

3) Biaya asuransi $=\frac{\text { Harga alat }(\mathrm{Rp}) \times 0,6}{\text { Umur pakai alat per tahun (jam) }} \times 0.03$

4) Biaya pajak $=\frac{\text { Harga alat }(\mathrm{Rp}) \times 0,6}{\text { Umur pakai alat per tahun (jam) }} \times 0.02$

5) Biaya perawatan dihitung dengan rumus berikut (Anonim, 1992) :

Biaya perawatan $=$ biaya penyusutan

6) Biaya bahan bakar dihitung sebagai berikut:

Biaya bahan bakar = Penggunaan bahan bakar (liter/jam) $\mathrm{x}$ harga bahan bakar per liter

(Rp/liter)

7) Biaya oli dan pelumas dihitung dengan rumus sebagai berikut (Anonim, 1992) :

Biaya oli dan pelumas $=0,1$ biaya bahan bakar

8) Upah dihitung dengan rumus :

$\mathrm{U}=\mathrm{T}: \mathrm{W}$

di mana: $\mathrm{U}=\mathrm{Upah}(\mathrm{Rp} / \mathrm{jam}) ; \mathrm{T}=$ Tarif upah per hari $(\mathrm{Rp} /$ hari); dan $\mathrm{W}=$ waktu kerja per hari (jam/hari).

\section{HASIL DAN PEMBAHASAN}

\section{A. Produktivitas Pengeluaran Kayu dengan Sistem Kabel}

Penelitian produktivitas dan biaya pengeluaran kayu dengan sistem kabel layang P3HH24 dilakukan di KPH Pekalongan Barat, PT Perhutani Unit I Jawa Tengah. Jarak bentangan kabel pada uji coba pengeluaran kayu dengan sistem kabel layang ini adalah $200 \mathrm{~m}$. Kelerengan areal adalah 20\%. Kayu yang dikeluarakan adalah jenis tusam (Pinus merkusii Yungh et de Vrise). Hutan tanaman yang dipanen berumur 39 tahun (tahun tanam 1963).

Hasil pengamatan pengeluaran kayu dengan sistem kabel layang menunjukkan bahwa waktu pengeluaran kayu per rit berkisar antara 0,05 - 0,12 jam/rit dengan rata-rata 0,08 $\mathrm{jam} /$ rit. Diameter kayu yang dikeluarkan dengan sistem kabel layang berkisar antara 20 - 51 $\mathrm{cm}$ dengan rata-rata $36 \mathrm{~cm}$. Jumlah batang yang dikeluarkan per rit berkisar antara 1 - 3 batang. Volume kayu yang dikeluarkan berkisar antara $0,040-0,500 \mathrm{~m}^{3} /$ rit dengan rata-rata 0,162 $\mathrm{m}^{3} /$ rit (Tabel 1). 
Tabel 1. Waktu kerja, diameter kayu, jumlah batang dan volume kayu per rit Table 1. Working time, log diameter, number of logs, and log volume per turn

\begin{tabular}{|c|c|c|c|}
\hline No & $\begin{array}{c}\text { Perihal } \\
\text { (Items) }\end{array}$ & $\begin{array}{l}\text { Selang nilai } \\
\text { (Range of value) }\end{array}$ & $\begin{array}{l}\text { Rata-rata } \\
\text { (Average) }\end{array}$ \\
\hline 1 & Waktu kerja (Working time), jam (bour) & $0,05-0,12$ & 0,08 \\
\hline 2 & Diameter kayu (Log diameter), $(\mathrm{cm})$ & $20-51$ & 36 \\
\hline 3 & $\begin{array}{l}\text { Jumlah batang (The number of log), potong } \\
\text { (pieces) }\end{array}$ & $1-3$ & 1,9 \\
\hline 4 & Volume kayu (Log volume) $\left(\mathrm{m}^{3}\right)$ & $0,040-0,500$ & 0,1629 \\
\hline
\end{tabular}

Tabel 2. Produktivitas pengeluaran kayu

Table 2. Log extraction productivity

\begin{tabular}{|c|l|c|}
\hline No. & \multicolumn{1}{|c|}{ Perihal (Items) } & Produktivitas (Productivities) \\
\hline 1 & Selang (Range), $\mathrm{m}^{3} / \mathrm{jam}\left(\mathrm{m}^{3} /\right.$ hour $)$ & $1,527-5,656$ \\
2 & Rata-rata (Mean), $\mathrm{m}^{3} / \mathrm{jam}\left(\mathrm{m}^{3} /\right.$ hour) & 2,519 \\
3. & Simpangan baku (Standard deviation) $\mathrm{m}^{3} / \mathrm{jam}\left(\mathrm{m}^{3} /\right.$ hour $)$ & 0,886 \\
4. & Koefisien variasi (Coefficient of variation), \% & 35,16 \\
\hline
\end{tabular}

Produktivitas pengeluaran kayu dengan sistem kabel layang P3HH24 berkisar antara 1,527 - 5,656 $\mathrm{m}^{3} /$ jam dengan rata-rata $2,519 \mathrm{~m}^{3} /$ jam (Tabel 2). Produktivitas tersebut masih dapat ditingkatkan dengan cara meningkatkan efektivitas penggunaan waktu kerja antara lain dengan mempercepat waktu persiapan. Produktivitas sistem kabel layang P3HH24 lebih rendah dari pada produktivitas kabel layang Isuzu 240, yaitu secara berurutan 2,519 $\mathrm{m}^{3} / \mathrm{jam}$ dibanding 21,060 $\mathrm{m}^{3} / \mathrm{jam}$. Hal ini disebabkan tenaga motor pada sistem kabel layang P3HH24 jauh lebih kecil dibanding tenaga motor sistem kabel layang Isuzu 240, yaitu secara berurutan 24 tenaga kuda dibanding 240 tenaga kuda.

Heinrich (1987) menyatakan bahwa di hutan tanaman di daerah pegunungan dengan kayu yang berukuran besar dan jaringan jalan rendah, sistem kabel layang secara tradisional mungkin dapat menjadi cara yang cocok untuk pemanenan kayu, baik secara tebang pilih maupun tebang jalur. Lebih lanjut dilaporkan bahwa sistem kabel layang di Bhutan dapat mengeluarkan kayu $20-25 \mathrm{~m}^{3}$ per hari. Apabila waktu kerja 8 jam per hari maka produktivitas sistem kabel layang yang berkekuatan sekitar 80 tenaga kuda di Bhutan tersebut berkisar antara 2,500 - 3,125 $\mathrm{m}^{3} / \mathrm{jam}$. Dibandingkan dengan produktivitas rata-rata sistem kabel layang di Bhutan, produktivitas kabel layang yang telah diuji coba dengan kekuatan tenaga tiga kali lebih kecil tidak jauh berbeda yaitu secara berurutan $2,519 \mathrm{~m}^{3} /$ jam dibanding 2,500 - 3,125 $\mathrm{m}^{3} /$ jam. Hal ini mengindikasikan sistem kabel layang P3HH24 masih lebih baik dibandingkan dengan sistem kabel layang yang ada di Bhutan. 
Pengeluaran kayu dengan sistem kabel layang Koller 300 telah dicoba di PT Sumalindo Lestari Jaya di Kalimantan Timur. Dulsalam dan Tinambunan (1998) menyimpulkan bahwa produktivitas alat sistem kabel layang Koller 300 (tidak termasuk waktu persiapan dan bongkar alat) per jalur kabel berkisar antara 1,040 - 2,980 $\mathrm{m}^{3} /$ jam dengan rata-rata 2,190 $\mathrm{m}^{3} /$ jam. Sedangkan produktivitas ekstraksi kayu termasuk waktu persiapan dan bongkar alat berkisar antara 1,460 - 1,850 $\mathrm{m}^{3} /$ jam dengan rata-rata 1,710 $\mathrm{m}^{3} /$ jam. Produktivitas rata-rata pengeluaran kayu dengan sistem kabel layang $\mathrm{P} 3 \mathrm{HH} 24$ dengan tenaga $24 \mathrm{HP}$ lebih tinggi bila dibanding dengan produktivitas rata-rata pengeluaran kayu dengan sistem kabel layang Koller 300 dengan tenaga mesin 50 HP di PT Sumalindo Lestari Jaya, yaitu secara berurutan 2,620 $\mathrm{m}^{3} /$ jam dibanding $1,710 \mathrm{~m}^{3} /$ jam.

\section{B. Biaya Sistem Kabel Layang}

Dengan mengetahui produktivitas dan data biaya pemilikan dan pengoperasian sistem kabel layang untuk penyaradan kayu maka biaya penyaradan kayu per $\mathrm{m}^{3}$ dapat dihitung. Biaya pemilikan dan pengoperasian alat dihitung berdasarkan data dasar yang tercantum pada Tabel 3 .

Tabel 3. Uraian dasar untuk perhitungan biaya pemilikan dan pengoperasian alat Tabel 3. Base items for calculating ownership and operation cost of equipment

\begin{tabular}{|c|c|c|c|}
\hline No & Uraian (Explanation) & Satuan (Unit) & Nilai (Value) \\
\hline 1 & Harga alat (Equipment price) & Rp/unit & 60.000 .000 \\
\hline 2. & Harga alat bekas (Salvage value) & $\%$ & 10 \\
\hline 3. & Umur pakai alat (Equipment live time) & Tahun (Year) & 5 \\
\hline 4. & $\begin{array}{l}\text { Jam kerja per tahun (Working hours } \\
\text { per year) }\end{array}$ & $\begin{array}{l}\text { Jam/tahun } \\
\text { (Hour/year) }\end{array}$ & 2000 \\
\hline 5. & $\begin{array}{l}\text { Jam kerja per hari (Working hours per } \\
\text { day) }\end{array}$ & $\begin{array}{l}\text { Jam/hari } \\
(\text { Hour } / \text { day })\end{array}$ & 8 \\
\hline 6. & Bunga bank (Bank interest rate) & $\%$ & 18 \\
\hline 7. & Harga solar (Diesel fuel price) & $\begin{array}{l}\mathrm{Rp} / \text { liter } \\
(\mathrm{R} p / \text { litre })\end{array}$ & 1.450 \\
\hline 8. & Upah (Wage) & $\begin{array}{l}\mathrm{Rp} / \text { hari } \\
(\mathrm{R} p / \text { day })\end{array}$ & 120.000 \\
\hline 9. & Asuransi (Insurance) & $\%$ & 3 \\
\hline 10. & Pajak (Tax) & $\%$ & 2 \\
\hline 11. & Biaya perawatan (Maintenance cost) & $\mathrm{Rp}$ & $\begin{array}{l}\text { Sama dengan biaya } \\
\text { penyusutan (The same as } \\
\text { depreciation cost) }\end{array}$ \\
\hline 12. & $\begin{array}{l}\text { Biaya oli atau pelumas (Lubrication oil } \\
\text { or grease cost) }\end{array}$ & $\mathrm{Rp}$ & $\begin{array}{l}0,1 \text { atau sepersepuluh } \\
\text { biaya bahan bakar }(0,1 \text { or } \\
\text { one tenth of fuel cost) }\end{array}$ \\
\hline 13. & Biaya sosial (Social cost) & $\%$ & 43 \\
\hline
\end{tabular}


Data dalam Tabel tersebut dikumpulkan pada tahun 2002 pada saat kurs (nilai tukar) US \$1 = Rp 9.000 .

Dari data biaya pada Tabel 3 tersebut, komponen biaya memiliki dan menjalankan alat pengeluaran kayu dengan sistem kabel layang dapat dihitung dengan hasil seperti disajikan pada Tabel 4.

Tabel 4. Biaya pengeluaran kayu dengan sistem kabel layang P3HH24 (Rp/jam) Table 4. Log extraction cost using P3HH24 skyline system (Rp/bour)

\begin{tabular}{|c|l|c|}
\hline No & \multicolumn{1}{|c|}{ Komponen biaya (Cost component) } & $\mathrm{Rp} / \mathrm{jam}$ (Rp/hour) \\
\hline 1 & Biaya penyusutan (Depreciation cost) & 5.400 \\
2. & Bunga bank (Bank interest) & 3.240 \\
3. & Asuransi (Insurance) & 540 \\
4. & Pajak (Tax) & 360 \\
5. & Biaya perawatan (Maintenance cost) & 5.400 \\
6. & Biaya bahan bakar (Fuel cost) & 2.900 \\
7. & Biaya oli dan pelumas (Lubrication oil and grease cost) & 290 \\
8. & Biaya upah (Wage cost) & 15.000 \\
9. & Biaya sosial (Social cost) & 6.450 \\
\hline & Jumlah (Total) & 39.580 \\
\hline
\end{tabular}

Biaya usaha pengeluaran kayu dengan sistem kabel layang P3HH24 adalah Rp 39.610/ jam yang terdiri dari Rp 5.400/jam biaya penyusutan, Rp 3.240/jam biaya bunga, Rp 540/jam biaya asuransi, Rp 360/jam biaya pajak, Rp 2.900/jam biaya bahan bakar, Rp 290/jam biaya oli dan pelumas, Rp 21.450/jam biaya operator dan pembantunya.

Biaya rata-rata pengeluaran kayu dengan sistem kabel layang diperoleh dengan membagi biaya pemilikan dan pengoperasian alat dalam Rp/jam (Tabel 4) dengan rata-rata produktivitas pengeluaran kayu dalam $\mathrm{m}^{3} / \mathrm{jam}$ (Tabel 2), yaitu Rp 39.580/jam : 2,519 $\mathrm{m}^{3} / \mathrm{jam}$ $=\operatorname{Rp} 15.713 / \mathrm{m}^{3}$. Biaya tersebut sebagian besar terdiri dari biaya menjalankan alat (Rp 11.925/ $\mathrm{m}^{3}$ atau $75,9 \%$ ) dan sisa dari biaya memiliki alat (Rp $3.787 / \mathrm{m}^{3}$ atau $24,1 \%$ ).

Biaya rata-rata pengeluaran kayu dengan sistem kabel layang P3HH20 yang telah disempurnakan adalah Rp 24.963/ $\mathrm{m}^{3}$ (Dulsalam \& Tinambunan, 2002). Biaya rata-rata pengeluaran kayu dengan sistem kabel layang $\mathrm{P} 3 \mathrm{HH} 24$ lebih rendah bila dibanding dengan biaya rata-rata pengeluaran kayu dengan sistem kabel layang $\mathrm{P} 3 \mathrm{HH} 20$ yang disempurnakan, yaitu secara berurutan $\mathrm{Rp} 15.724 / \mathrm{m}^{3}$ dibanding $\mathrm{Rp} 24.963 / \mathrm{m}^{3}$. Biaya rata-rata pengeluaran kayu dengan sistem kabel layang Koller 300 adalah Rp 33.322/ $\mathrm{m}^{3}$ (Dulsalam \& Tinambunan, 1998). Biaya rata-rata pengeluaran kayu dengan sistem kabel layang Koller 300 jauh lebih tinggi dibanding biaya rata-rata pengeluaran kayu dengan sistem kabel layang P3HH24, yaitu secara berurutan Rp 33.322/ $\mathrm{m}^{3}$ dibanding $\mathrm{Rp} 15.119 \mathrm{~m}^{3}$. Biaya rata-rata pengelauran kayu secara tradisional di tempat penelitian, menurut tarif upah dari Perum Perhutani adalah 
Rp 20.000/ $\mathrm{m}^{3}$, di mana jauh lebih tinggi dari biaya pengeluaran kayu dengan sistem kabel layang P3HH24. Dengan demikian pengeluaran kayu dengan sistem kabel layang P3HH24 layak untuk diaplikasikan (diterapkan).

\section{KESIMPULAN DAN SARAN}

Dari hasil dan pembahasan dapat ditarik kesimpulan sebagai berikut:

1. Pengoperasian kabel layang $\mathrm{P} 3 \mathrm{HH} 24$ untuk mengeluarkan kayu di hutan tanaman KPH Pekalongan Barat dapat berjalan lancar.

2. Diameter kayu yang dikeluarkan dengan sistem kabel layang P3HH24 berkisar antara 20 $51 \mathrm{~cm}$ dengan rata-rata $36 \mathrm{~cm}$ sedangkan jumlah batang yang disarad per rit (satu tahap operasi) berkisar antara 1 - 3 batang.

3. Volume kayu yang disarad dengan sistem kabel layang P3HH24 berkisar antara 0,040 $0,500 \mathrm{~m}^{3} /$ rit dengan rata-rata $0,163 \mathrm{~m}^{3} /$ rit.

4. Produktivitas pengeluaran kayu dengan sistem label layang P3HH24 berkisar antara 1.527 $-5,656 \mathrm{~m}^{3} /$ jam dengan rata-rata $2,519 \mathrm{~m}^{3} / \mathrm{jam}$.

5. Biaya rata-rata pengeluaran kayu dengan sistem kabel layang $\mathrm{P} 3 \mathrm{HH} 24$ adalah $\operatorname{Rp} 15.713 / \mathrm{m}^{3}$.

6. Dibandingkan dengan tarif upah pengeluaran kayu setempat, pengeluaran kayu dengan sistem kabel layang P3HH24 jauh lebih murah sehingga layak diusahakan.

7. Untuk pengeluaran kayu dari areal yang mempunyai kelerengan 15\% atau lebih disarankan untuk menggunakan kabel layang P3HH24 agar pekerjaan dapat berjalan lebih efektif dan biaya lebih murah.

\section{DAFTAR PUSTAKA}

Anonim. 1992. Cost control in forest harvesting and road construction. FAO Forestry Paper No. 99. FAO. Rome.

Binkley, V.W \& H.H. Lysons. 1968. Planning single span skyline. U.S. Department of Agriculture, Forest Service. Oregon.

Brown, N. C. 1949. Logging. The Principle of Method of Harvesting Timber in The United States and Canada. John Wiley and Sons Inc. New York.

Dulsalam, M. M. Idris \& W. Endom. 1997. Produktivitas dan biaya pengeluaran kayu dengan sistem kabel P3HH20. Buletin Penelitian Hasil Hutan 15(3):151-161. Pusat Penelitian dan Pengembangan Hasil Hutan. Bogor.

Dulsalam \& D. Tinambunan. 1998. Studi kasus produktivitas dan biaya pengeluaran kayu dengan sistem kabel layang Koller 300. Buletin Penelitian Hasil hutan 16(5):231-253. Pusat Penelitian dan Pengembangan Hasil Hutan. Bogor. 
Dulsalam \& D. Tinambunan. 2002. Uji coba pengeluaran kayu di hutan tanaman Pulau Laut dengan sistem kabel layang P3HH20 yang disempurnakan. Buletin Penelitian Hasil Hutan 20(4):313-331. Pusat Penelitian dan Pengembangan Teknologi Hasil Hutan. Bogor.

Heinnrich, R. 1987. Appropriate wood harvesting in plantation forest in developing countries. FAO Forestry Development Paper No. 78. FAO. Rome.

Laban, B. Y. 2004. Kebijakan restrukturisasi industri kehutanan berbasis pengelolaan hutan lestari. Prosiding Ekspose Hasil-Hasil Litbang Hasil Hutan dalam Mendukung Program Restrukturisasi Industri Kehutanan, tanggal 16 Desember 2003 di Bogor. Hlm. 7-18. Pusat Penelitian dan Pengembangan Teknologi Hasil Hutan. Bogor.

Wackerman, A. E. 1949. Harvesting Timber Crops. McGraw-Hill Book Company Inc. New York. 